\title{
The "ASEAN Way": A Sore Thumb for ASEAN Solidarity in the Face of an Ailing Global Trade System?
}

\author{
Noel Chow Zher Ming*
}

"Standards and integrity are for Oscar winners. Everybody else has to bend over". (lan Arkin's character, Norman Newlander, to Sandy Kominsky (Michael Douglas) in The Kominsky Method, 2019).

The Kominsky Method is a comedy series starring Michael Douglas as Sandy Kominsky, a once successful actor turned acting coach, and Alan Arkin as Norman Newlander, his recently widowed agent. Both are in their latter years. Newlander retorts with this line when Kominsky attempts to explain why he turned down numerous career enhancing opportunities in his younger years. When we strip away the fictional characters, setting and circumstances, the substance of this retort represents a struggle that is far from fictional. For many years, scholars who identify themselves as being advocates of Third World Approaches to International Law (TWAIL) have argued that the "Oscar winners" of the international community, the America and the Eurocentric West, who could afford to have standards and integrity, proceeded to shape international law with these standards and then imposed them on everyone else under the brand of human rights, civil liberties and the rule of law. TWAIL developed as a response from the "everybody else", the colonized Third World, which had to bend over.

Southeast Asia's participation in international law is uniquely recent, but important. The region was only recently decolonized, culturally and politically diverse, experiencing unprecedented economic and population growth, and integrated into the international legal order. But it is at the same time considered to be the birthplace (geographically at least) of the Third World's response to mainstream international law scholarship traditionally dominated by Western powers with a colonial lineage. The Bandung Conference of 1955 became an assembly of like-minded, recently independent and mostly Asian

* General Manager, Singapore \& Malaysia, Tradewin Asia. 
and African states tired of colonialism and hungry for self-determination. ${ }^{1}$ Whether or not the TWAIL movement itself actually emerged from this conference is a subject of some subjectivity and of less importance in comparison to the significance of the fact that it remains today both a TWAIL landmark and a rallying point. ${ }^{2}$

As an ideology, the TWAIL scholarship challenges the mainstream "Eurocentric" international legal order in that it "1) uses colonial history to frame the impact of international law on the South; 2) avoids prioritizing the universal above the local; and 3) focuses on the interrelation between international capital and non-European cultural traditions". ${ }^{3}$ A monolithic approach to characterizing international law in [South] and Southeast Asia, as one Southeast Asian scholar describes, "does little justice to the regions' rich diversity and complex history". ${ }^{4}$ Herein lies the central theme of this article. What is Southeast Asia's ideological identity to begin with? What would a multilateral legal system that could do justice to the region's rich diversity and complex history look like? If such a thing were to exist, how would it work? Enter the Association of South East Asian Nations (ASEAN).

While ASEAN is often portrayed as being culturally, socio-economically, ethnically and of course ideologically diverse, with very little common ground as an impetus for integration, many of these prickly differences interestingly emerged during decolonisation, Newly formed sovereign states started grappling for regional influence, trying to make the most of what their respective former colonial masters left behind, inevitably trampling over each other's toes in the process, especially naturally when it came to issues of borders, national security and national identity.

Early Southeast Asian legal culture really only emerged from three principal clusters of legal tradition. Desierto explains that "Buddhist kingdoms in Burma, Thailand, and Laos drew from Buddhist texts providing ethical rules of conduct through theistically-driven conceptions of obligation".5 Coastal

1 See R.P. Anand, Studies in International Law and History: An Asian PerSpective 1, 1-23 (2004); The Ministry of Foreign Affairs Republic of Indonesia, Asia-Africa SPEAK From BANDUNG 161-69 (1955), http://franke.uchicago.edu/Final_ Communique_Bandung_1955.pdf.

2 Id.

3 Andrew F. Sunter, TWAIL as Naturalized Epistemological Inquiry, 20 CANADIAN Journal OF LAW AND JURISPRUdENCE 475, 487 (2007).

4 Diane A. Desierto, Postcolonial International Law Discourses on Regional Developments in South and Southeast Asia, 36 International Journal of Legal Information 387, 392 (2008).

5 Id. at 416. 
kingdoms along the Malay peninsula that make up modern-day Malaysia, Indonesia, Brunei, Singapore and the Southern Philippines drew heavily from Islamic law, characterized by the Quran and Sharia. ${ }^{6}$ Early inland societies in Burma, Siam, Champa and Khmer (roughly spanning the modern-day Indo-Chinese cluster of Thailand, Cambodia, Myanmar, Laos and Vietnam) as well as Java owe most of their legal traditions to Hindu rules of moral and social conduct which "codified law in ten categories and solved disputes through collective decision-making (mushawara-mufaqat).". This concept of mushawara-mufaqat, of consensus and collective decision-making, is exactly what has found its way into modern-day ASEAN regionalism, in what has evolved into the "ASEAN Way". Sometimes used fondly as a collective regional identity almost akin to "ASEAN state(s) practice", it was too often also used as a derogatory euphemism for talk and no action. If there was such a thing that embodied a multilateral system that "does justice to a [non-European] region's rich diversity and complex history" in a way that TWAIL scholarship imagines, this is probably as close as it gets. ${ }^{8}$ But does it work? The next several chapters critically analyse this.

\section{What is Wrong at the Global Level and How is It Affecting ASEAN?}

We will consider several sides of the story in this article, each one briefly. For the sake of simplicity, let me start with Donald Trump and the US. Trump and his advocates have from even before his presidency accused the wTO of being the "worst trade deal ever". ${ }^{9}$ Then at the start of his presidency, he threatened to pull out of the WTO, accusing the organization of needing to "shape up", 10 citing abuse of the "special and differential" treatment provision for developing countries as a principal reason. In 2018, the White House issued a memo to the US Trade Representative, calling on the wто to review the way in which it grants "developing country" status. The memo cites 11 countries, including

\footnotetext{
$6 \quad I d$.

7 Id.

$8 \quad$ Id. at 392.

9 David A. Wemer, What is Wrong With The WTO?, Atlantic Council (June 14, 2019), https://www.atlanticcouncil.org/blogs/new-atlanticist/what-is-wrong-with-the-wto/.

10 John Micklethwait et al., Trump Threatens to Pull U.S. Out of WTO if It Doesn't 'Shape Up', BLOомвеRG (Aug. 31, 2018, 4:52 PM), https://www.bloomberg.com/news/articles/ 2018-o8-3o/trump-says-he-will-pull-u-s-out-of-wto-if-they-dont-shape-up.
} 
Kuwait, Macao, Mexico, Qatar, Singapore, South Korea, Turkey, the United Arab Emirates and China. ${ }^{11}$ Trump himself tweeted:

When the wealthiest economies claim developing-country status, they harm not only other developed economies but also economies that truly require special and differential treatment. Such disregard for adherence to WTO rules, including the likely disregard of any future rules, cannot continue to go unchecked. ${ }^{12}$

US Trade Representative Robert Lighthizer echoed the tweet saying:

[F]ar too long, wealthy countries have abused the wTo by exempting themselves from its rules through the use of special and differential treatment. This unfairness disadvantages Americans who play by the rules, undermines negotiations at the WTO, and creates an unlevel playing field. I applaud the President's leadership in demanding fairness and accountability at the WTO. ${ }^{13}$

The EU and Japan have similarly expressed the need for reform at the WTO and have also been largely critical of China and others who have benefitted tremendously from "gaming" the WTO system, only nowhere near the intensity of Trump's US, and are certainly not in favour of using tariffs to reform the wTo. ${ }^{14}$ This may seem like the tipping point, but it would be naïve to think that this was the sole grievance the multilateral system had to contend with. Rather, it is one of many festering within the multilateral trading system. Differences between trading partners existed from the start and pre-date the WTO. In fact, so deep-rooted, numerous and varied were the challenges affecting multilateral trade that it came to be the reason a rules-based governing organization in the form of the WTO never came into being until $1994 .{ }^{15}$ It is

11 The White House, Memorandum on Reforming Developing-Country Status in the World Trade Organization (July 26, 2019), https:/www.whitehouse.gov/presidential -actions/memorandum-reforming-developing-country-status-world-trade-organization. Kenneth Rapoza, Trump the Trade Tyrant Targets the WTO, Fonbes (July 29, 2019, 10:00 AM), https://www.forbes.com/sites/kenrapoza/2019/o7/29/trump-the-trade-tyrant -targets-the-wto/\#42c5c6or65f8.

13 Id.

14 EU Trade Commissioner Expresses Support for Japan's Goal to Reform WTO, THE JAPAN Times (Nov. 24, 2018), https://www.japantimes.co.jp/news/2018/11/24/business/eu-trade -commissioner-expresses-support-japans-goal-reform-wto/\#.XYXmYC2 $2 \mathrm{Q}_{1 T Y}$

15 Daniel Drache, The Short but Significant Life of the International Trade Organization: Lessons for Our Time (Centre for the Study of Globalisation and Regionalisation, Working Paper No. 62/oo, 200o), https://core.ac.uk/download/pdf/4753o.pdf. 
not the interest of this article to visit each one of them. They are complex and multi-faceted in nature.

What is important, though, is to accept that every member of the multilateral trading system has at some point chosen national interests over multilateralism, and will continue to do so for a variety of reasons, sometimes out of necessity and sometimes even against its own leader's desire. This is not a matter of Europeans and Americans vs. the Third World. Whatever the reason, each time a state elects to choose national interests over multilateralism, the rules-based institution erodes, no matter how apologetic the perpetrator is. With 164 current WTO members, ${ }^{16}$ the odds only stand to increase.

In saying that, we now consider the perspective of the wTO itself. The WTO itself is the product of a compromise - of a "diplomat's jurisprudence" as Robert E. Hudec puts it. ${ }^{17}$ It operates on the principle of "consensus" decision making. Democratic and transparent in principle, but hugely inefficient. Attempting to reach a consensus among 164 members on issues laden with overlapping national interests is the equivalent of a hunt for a unicorn. Often cited as the epitome of compromise (or failure, depending on how you look at it), WTO members in 2001 embarked on a massive attempt to update the WTo's outdated rules in Doha in what is now known as the Doha Development Agenda:

The participating countries spent years trying to reach an agreement. Ultimately, the attempt largely fizzled out and resulted in a much more modest agreement on trade facilitation. A central problem in negotiation was the difficulty of getting well over 150 countries to reach consensus. In the previous negotiating round, potential hold-out countries could be threatened with exclusion from the new WTO. That trick could not be repeated once they were already in..$^{18}$

The "much more modest agreement on facilitation" was concluded in Bali in 2013, known informally as the Bali Package. ${ }^{19}$ Finally, we consider the perspective of the developing world - by far the most difficult to characterize. It is

16 Members and Observers, World Trade Organization, https://www.wto.org/english/ thewto_e/whatis_e/tif_e/org6_e.htm.

17 Noel Chow Zher Ming, Professor Hudec's "Techniques of the Diplomat's Jurisprudence": Does It Still Apply?, 6 Asian JournaL OF LAW AND Economics 23, 26 (2015).

18 Phil Levy, What's Wrong with the World Trade Organization, Fonbes (Oct. 30, 2018, 5:53 AM), https://www.forbes.com/sites/phillevy/2018/10/30/whats-wrong-with-the -world-trade-organization/ $\#_{5} \mathrm{df}_{2} 755$ еза49.

19 Bali Package and November 2014 Decisions, World Trade Organization, https:// www.wto.org/english/thewto_e/minist_e/mc9_e/balipackage_e.htm. 
neither a single entity, nor is it entirely united with its grievances. We will have to make do with some broad examples and generalisations. To draw on The Kominsky Method parallel again, developing countries have traditionally felt they were perpetually bending over, marginalised from consensus decisionmaking. At the start of multilateral trade negotiations in the 1940's-50's, developing countries became increasingly fearful that liberal trade policies being negotiated at the General Agreement on Tariffs and Trade (GATT) would eventually be forced on them and impede the development of infant industries which was believed to be necessary for industrialization. This in turn was believed to be necessary for developing countries to progress from dependence on low value exports of primarily raw materials to higher value productions. ${ }^{20}$ Over years of negotiation, they eventually felt that their needs were not sufficiently addressed in the GATT.

Partly because developing countries felt that their trade concerns were not being effectively addressed in the GATT, they lobbied for and succeeded in the establishment of a separate organisation to deal explicitly with problems of trade and development. This organisation, the United Nations Conference on Trade and Development (UNCTAD) came into being in 1964, and became the main institution through which developing countries tried to pursue their international trade agenda during this period. The establishment of a system of preferences for developing country exports of manufactures in developed country markets and stabilisation of commodity trade were important topics on the Agenda of the new institution over the decades of the 1960's and 1970's. ${ }^{21}$

By 1968, developing countries had succeeded at extracting preferences from developed countries under a Generalised System of Preferences (GSP), a system allowing developing countries a variety of trade preferences without the need to reciprocate. It is not legally binding but observed by most developed countries on a voluntary basis, eventually becoming entrenched in the WTO agreements as "special and differential treatment" (S\&D) for developing and least developed countries. ${ }^{22}$ Clearly, there are now incentives for being a developing country at the WTO and it has not been difficult to "become" one. No method was negotiated or agreed on as to how a "developing country" was

\footnotetext{
20 Constantine Michalopoulos, The Role of Special and Differential Treatment for Developing Countries in GATT and the World Trade Organization (Policy Research Dissemination Center, Working Paper No. 2388, 200o).

$21 \quad I d$.

22 Id. at 15.
} 
to be defined, so countries identified as such were regarded as such. This certainly puts Trump's and Lightizer's accusations against the WTO into context.

Developing countries' responses to the US' unilateral action naturally varied. India promptly retaliated with tariffs after having been struck off the US GSP, ${ }^{23}$ and Singapore simply reiterated over media that it was not abusing developing country status at the WTO, ${ }^{24}$ while Indonesia, faced with the prospect of a review of its GSP status in addition to hefty anti-dumping measures against its biofuel and textile exports, began lobbying to maintain friendly trade ties with the US. ${ }^{25}$ South Korea, whose washing machine exports were amongst the first commodities to be struck with "America First" tariffs, brought the measure to the WTO where the arbitration panel ruled recently in its favour. ${ }^{26}$ Vietnam took a goodwill approach - in its attempt to placate the US, it pledged to import more US goods to narrow its trade deficit. ${ }^{27}$ China, given very little room to wriggle, responded with retaliatory tariffs while continuing to labour away at a trade deal with the US. ${ }^{28}$

So where does all this leave ASEAN? The answer lies in ASEAN's vulnerability to these external shocks vis-à-vis its participation in, and dependence on, the multilateral trade system and its institutions.

This is an important question given that much of TWAIL scholarship is a reflection on the mainstream international law's failure to consider the plight of the non-European world. This was an easier argument to make in the 1950's,

23 India Announces Retaliatory Trade Tariffs Against the US, ввс NEWs (June 15, 2019), https://www.bbc.com/news/world-asia-india-48650505.

24 US Aware Singapore Doesn't Take Advantage of Developing-Country Status: Chan Chun Sing, The Straits Times (Aug. 2, 2019, 5:OO AM), https://www.straitstimes.com/world/ united-states/us-aware-singapore-doesnt-take-advantage-of-developing-country-status -chan.

25 Linda Yulisman, Indonesia Lobbying to Maintain US Trade Ties, The Straits Times (July 28, 2018, 5:०0 AM), https://www.straitstimes.com/asia/se-asia/indonesia-lobbying -to-maintain-us-trade-ties.

26 WTO Awards S. Korea $\$ 85$ mln Against U.S. Over Washing Machine Tariffs, Reuters (Feb. 9, 2019, 12:28 AM), https://www.reuters.com/article/usa-trade-southkorea-wto/wto -awards-skorea-85-mln-against-us-over-washing-machine-tariffs-idUSL5N203567.

27 Vietnam Buys More US Goods After Trump Calls It Trade Abuser, The Straits Times (June 29, 2019, 1:27 PM), https://www.straitstimes.com/asia/se-asia/vietnam-buys-more -us-goods-after-trump-calls-it-trade-abuser.

28 Keith Bradsher \& Ana Swanson, Despite Tough Talk, U.S.-China Trade Negotiations Continue, N.Y. Times (Sept. 21, 2019), https://www.nytimes.com/2019/og/21/business/ united-states-china-trade.html. 
perhaps even up to the 70's and 80's when a combination of post-colonialism and pre-industrialisation in the East and deep south made those distinguishing features prominent. Global income inequality is narrowing between wealthy and lower income states. ${ }^{29}$ While there is a long way to closing that gap, India and China are certainly not needy anymore. ${ }^{30}$ The same can be said for South Korea, Singapore and Malaysia. To put it quite plainly, we are past the stage where the global economic order can be split geographically between "liberal" and "protectionist", "capitalist" and "socialist" or "developed" and "developing".

What we are witnessing today is globalization in its truest form. Maybe not in the way economists and diplomats predicted but, rather, the ugly reality of it. It is everybody wanting their version of the wTO. For much of the postWorld War II period, a multilateral trading system premised on liberal trade values and the rule of law was championed by the US, its European allies and Japan. This was something met, as we discussed in the previous section, with resistance from emerging economies whose industries had not yet developed, forcing the introduction of provisions in the GATT and WTO agreements for special and differential treatment for developing countries. Articulating this resistance, Linarelli, Salomon and Sornarajah in "The Misery of International Law" describe S\&D as "principally a failed pre-Uruguay Round approach to promoting the interests of developing countries". ${ }^{31}$ They highlight four problems with S\&D:

First, they specify special and differential treatment only for developing countries. Problems of justice found in the current trade architecture apply not only to states as an aggravated whole but to groups and even individuals within states. Second, they specify favoured treatment as something exceptional in the trade architecture. As explained below, one preferable option would be to write rules directly into the code of trade agreements that meet standards of justice. The aim should be to get the basic structure right in the first instance, not to get it wrong and then append dubious fixes. Third, special and differential treatment rules are too narrow because their aim is only to promote trade, when

29 Zsolt Darvas, Global Income Inequality is Declining Largely Thanks to China and India, BRUEGEL (Apr. 19, 2018), https://bruegel.org/2018/o4/global-income-inequality-is -declining-largely-thanks-to-china-and-india.

$30 \quad$ Id.

31 John Linarelli, Margot E. Salomon \& Muthucumaraswamy Sornarajah, The Misery of International LaW: Confrontations with Injustice in the GLOBAL ECONOMY 131 (2018). 
international agreements about trade must get the basic conditions of justice for economic arrangements between states right. Fourth and perhaps most importantly, they fail to produce any meaningful assistance through a predistributive scheme for developing countries. ${ }^{32}$

Beyond S\&D, Linarelli et al highlight an entire system of ideas within the context of international economics dominated by developed Western countries which the authors claim is responsible for "immiseration" - the term of choice, at the expense of low-income states. One aspect of that system we address more extensively in this article is the role of multinational corporations in that chain of immiseration. Of foreign investment, the authors argue:

While it is true that employment is created, the possibility that labour is treated otherwise than in accordance with accepted standards creates grave concerns. The environmental depletion that foreign investment may cause must be factored in. There are malpractices such as corruption, transfer pricing, and tax avoidance that reduce significantly the advantages of foreign investment. ${ }^{33}$

They further highlight:

Multinational corporations and shareholders reap the benefits of such liberalization. A minority of people in the developed states, who are shareholders of large multinational corporations, benefit from such foreign investment. The other citizens of the developed states might not directly benefit. The clear majority of the citizens of the developing countries into which such investments flow do not benefit from them. ${ }^{34}$

ASEAN's collective participation in the international economic order, however, does not suggest that this is the contemporary regional consensus. For several reasons, amongst them, this view presents a dangerously distorted image of the symbiotic relationship between multinationals and other actors involved in a thriving emerging economy. The result is that it presents multinationals as, to borrow an expression from Gary Quinlivan, "amoral government-manipulating rent-seeking monoliths that exploit the lack of environmental regulations and

$\begin{array}{ll}32 & I d . \\ 33 & I d . \text { at } 151 . \\ 34 & I d .\end{array}$


cheap foreign labor in developing countries" ${ }^{35}$ Consequently, the message it sends is the equivalent of saying that in a mortgage transaction, the only people who benefit are a few investors, not the home owners who otherwise would not be able to afford a home, not the banks who lend the money, nor the bank's employees, nor the shops in the new neighbourhood.

Such a view ignores the reality that developing countries, including ASEAN members, have benefitted as much from foreign investment brought about by multinationals as multinationals have from access to their markets. It also refrains from recognising that multinationals "do not operate with immunity", 36 to borrow from Quinlivan again. Very often, companies are themselves victims of the very malpractices and corruption the authors refer to. While transfer pricing and "tax avoidance that reduce significantly the advantages of foreign investment" do exist, to say that governments of lower income countries are better off without the taxes multinationals pay, even if grossly manipulated for argument's sake, is a misperception of how and why corporates deploy transfer pricing tactics. ${ }^{37}$

Often when multinationals adjust their transfer prices, it is to mitigate tax exposure in high tax jurisdictions. This has the natural result of actually being more detrimental to developed countries, often high-tax welfare states, than to developing countries. There are at the same time many aspects of doing business in less developed countries, and in particular in developing ASEAN countries that are a risk and therefore a cost that either erode their profitability or get passed on to buyers. Ultimately, there will be winners and losers, but to say that an injection of capital is the only thing multinationals bring when they invest abroad is a very narrow view.

Very often, lower income countries welcome the direct and indirect taxes (e.g., through customs tariffs on imported goods) generated through the foreign entity's tax residence, the building of infrastructure, transfer of knowledge, skills development, job creation and what Quilivan calls the "crowd economy" created when an ecosystem of suppliers and service providers, many of whom local, gather around the foreign investor and prosper. It may displace the local economy - far left/right advocates often play this card when advocating their views, but is there a more effective way to generate growth and income in a short time? The rising tide raises all boats as the saying goes, and the evidence

35 Gary Quinlivan, Sustainable Development: The Role of Multinational Corporations (Nov. 28, 2013) (unpublished manuscript).

$36 \quad$ Id.

37 Richard Rubin, Does Amazon Really Pay No Taxes? Here's The Complicated Answer, The Wall Street Journal (June 14, 2019, 5:30 AM), https://www.wsj.com/articles/ does-amazon-really-pay-no-taxes-heres-the-complicated-answer-11560504602. 
seems to suggest as much. In the case of ASEAN, its GDP grew from 23 in 1967 to 719 in 1997, before dipping to 577 in 1999, as a result of the Asian financial crisis in 1997. It then experienced exponential growth for the next two decades, peaking at 2,720 in $2017 .^{38}$ The reality of it all is that ASEAN has benefited from the legal order brought about by the multilateral trading system in its current structure. To borrow overused Brexit terminology, "hard" TWAIL probably stands only to make matters worse for ASEAN at this time. But that multilateral trade system is at the same time falling apart and ASEAN is in no position to single-handedly administer a solution to the global problem. For the time being, the only realistic Plan B is to tighten regional solidarity and weather the storm.

\section{The Need for Solidarity}

Weathering a storm is better done in numbers than as individuals. We again emphasise that this work is not a defence of the developed world or of multinational corporations. Nor is it an invitation for lower income countries to turn their backs on the multilateral system and stand on their own feet instead. The global multilateral system is in dire need of reform, but this requires consensus and states cannot be expected to wait indefinitely for consensus. At the same time, abandoning multilateralism in a time of increasing polarization will very likely lead only to even more polarization and, in the worst case, civil unrest. Instead, the message is this: an ASEAN pursuit of regional self-sufficiency will empower it, not only to weather a storm, but also to be a net contributor in the quest to reform the multilateral system.

By "self-sufficient" we certainly do not mean isolation from the global trade system. Far from it, it means building the regional alliance for more effective participation in it. In a global economic climate as volatile as this, ASEAN needs the collective strength of that regional alliance. At the same time, ASEAN as an alliance is probably a greater asset to the multilateral system than the sum of its parts. The starting point has pretty much been cut out by circumstances. With the US taking the lead, the developing world is already being accused of unfair trade practices, and a rational response is needed.

Such a response will inevitably involve change on the part of ASEAN. While change is difficult, it is often only immediate and radical changes that are

38 David Wijeratne, How to Keep the ASEAN Economies Growing for Another 50 Years, World ECONOMIC Forum (Sept. 12, 2018), https://www.weforum.org/agenda/2018/og/ to-keep-growing-aseans-economy-must-adapt-heres-how. 
uncomfortable. "Soft", gradual change on the other hand is perceived as less threatening. ASEAN's first step should be to close ranks and form a stronger alliance. The benefits of this are multi-faceted. For one, ASEAN member states individually benefit from the protection of a herd. But more importantly, the WTO as an institution benefits from the prospect of reduced discord. In an ideal world, ASEAN's differences would have been sorted within the ASEAN community. Of course, this is not an ideal world. So while it is easy to say, it is deceptively difficult to articulate and even more difficult to implement. We start by giving credit where credit is due. ASEAN is already on a journey to integration, and progressing steadily towards advanced cooperation. It is already recognized by global peers as a model of success for regionalism. ${ }^{39}$ It is only that the journey ahead is fraught with challenges that constantly delay progress. In the subsequent sections, we describe some of these challenges in more detail.

The policy angle to effect rules-based regionalism has been well studied and documented. In fact, the ASEAN member states have long expressed a desire for integration towards a rules-based community underscored by the rule of law. The National University of Singapore's Center for International Law's published series entitled "Integration Through Law" documents this journey from multiple aspects, including economic, legal and trade policy. The focus of that series is, like in many academic works, on the state (ASEAN member states) and the institution (ASEAN). This article takes a different perspective by taking a deeper dive into non-state contributors to the ecosystem, especially the likes of the private sector (including the begrudging foreign multinational), public administrators and private interest groups that when mobilized effectively can be extremely effective at achieving that desired rules-based alignment. In saying that, it still must start at the top - at the regional policy level. So there is a need to dissect the "ASEAN Way", the DNA of ASEAN culture for many years, and explain why this must first modernize in order for the medicine to work, figuratively speaking.

For this "survival pact" (for the lack of a better expression) to have the best chance of success, it needs to be put in place before the multilateral trading system suffers further unexpected shocks. For a start, ASEAN needs to remain

39 Kishore Mahbubani \& Kristen Tang, ASEAN: An Unexpected Success Story, The Cairo Review of Global Affairs, https://www.thecairoreview.com/essays/asean-an -unexpected-success-story. 
viable in as many ways as possible - but especially so in terms of peace, stability and economic prosperity. This may be stating the obvious - ASEAN's very foundation is premised on these principles, but it is not going to happen on its own. There is no shortage of ways to introduce such a pact into the ASEAN machinery - a memorandum of understanding, a ministerial joint declaration, perhaps even an amendment to the ASEAN trade agreements, with language appealing to ASEAN members to prioritise regional interests. Ultimately, these are all only vessels, and they will only be as effective as the member states want them to be. Of essence is the substance, not the form. What is it going to take for ASEAN's individual members to adopt regional commitments over national (self) interest? ASEAN, or the sum of its parts rather, is well known to have had a long, stubborn history of resistance to reform. This stubbornness in turn owes part of its heritage to the "ASEAN Way". Heydarian sums the issue in the following way:

To many regional leaders, the so-called "Asean Way", where consultation and consensus underpin collective decision-making, is sacrosanct. After all, the traditional operating system allowed a highly diverse region to establish a community of peace and prosperity.

Yet, as years go by, the Asean Way is proving to be a primary obstacle rather than an enabler of deeper regional integration.

To begin with, this is because of the fundamental misinterpretation of "consensus" as "unanimity". In sensitive areas of decision-making, where protracted discussions and irreconcilable differences are almost inevitable by nature, this has become a recipe for disaster. Instead of action, there is paralysis.

The obsessive and obstinate search for unanimity effectively gives each member state, regardless of its size or interest, a de facto veto power over the future of Asean and, by extension, the whole region. ${ }^{40}$

There is one other feature of the ASEAN way which Heydarian does not bring up in his article, and a far more serious impediment to the outcome the author of this article is advocating. It is ASEAN's obsessive and obstinate adherence to the principle of non-interference. As a result of which, for sensitive areas of decision-making each member has the right to veto, as Heydarian describes, this is if the issue is even discussed. Many issues are simply passed off as being too sensitive to discuss on grounds of non-interference. If consultation and consensus is sacrosanct, non-interference is the first commandment. 
Such a principle would have suited ASEAN's development in the early days, when most Southeast Asian countries were newly decolonised and sovereignty became a treasured possession. But it is now often used as a polite way of expressing unwillingness to cooperate.

Because the principle of non-interference trumps all else, other states tend to oblige in keeping with the ASEAN way. The Rohingya crisis in Myanmar is an often-cited example of the non-interference principle impeding collective action, ${ }^{41}$ but this is an extreme case and in my opinion not the most helpful example. It is a thorny issue which involves elements of national security, human rights, and ethnic and socio-economic discord within a sovereign country's territory, which is something any country will be extremely cautious with getting involved in, irrespective of any prevailing regional principle of non-interference. Indonesia's repeated refusal to accept assistance to combat transboundary haze is another often cited example of ASEAN's toothless bite when a member country plays the sovereignty card over a cross-border issue. ${ }^{42}$ This is again an extreme example, given the prospect that delivering the assistance would involve one or more countries entering Indonesia's sovereign border, with no doubt, giving the recipient country a legitimate (if not moral) reason to claim interference in domestic affairs. Neither situation was fully within ASEAN's control to act in the sense that firstly both involved navigating prickly issues of sovereignty, and secondly help could not be imposed on an unwilling recipient, unless there were provisions within international law to permit it.

A much deeper level of trust is needed between states before cooperation on such sensitive issues is even conceivable. ASEAN has not yet developed this level of mutual trust, but there are many less prickly areas to drive reform without being enough of a threat for any one member to raise the noninterference shield. Many of these reside in the realm of customs, trade and border clearance policies - all 10 ASEAN members desire economic cooperation after all. ${ }^{43}$ From the ASEAN Economic Community (AEC) to the ASEAN Single Window (ASW), economic cooperation came to be a significant tool for

41 Angshuman Choudhury, Why Are Myanmar's Neighbors Ignoring the Rohingya Crisis?, The Diplomat (Sept. 25, 2018), https://thediplomat.com/2018/o9/why-are-myanmars -neighbors-ignoring-the-rohingya-crisis.

Yiswaree Palansamy, Accept Neighbours' Help to Fight Haze Now, Jakarta Post Urges Indonesia, MALAY MAIL (Sept. 22, 2019, 10:32 AM), https://www.malaymail.com/news/ malaysia/2019/o9/22/accept-neighbours-help-to-fight-haze-now-jakarta-post-urges -indonesia/1793og6.

43 Simon Chesterman, From Community to Compliance?: The Evolution of Monitoring Obligations in ASEAn 12 (Joseph H.H. Weiler et al. eds., 2015). 
ASEAN cooperation after $1976 .{ }^{44}$ It is also successful cooperation in this area that is in many ways driving the rules-based integration. Of course, there are limits to any model of success, and it is important to remain grounded, keep ourselves in check and reflect on the challenges that remain.

ASEAN, individually and collectively (with perhaps the exception of Singapore and Brunei), has remained extremely ineffective in dealing with bureaucracy, red tape and obstructions to business operations, which in turn obstructs ASEAN members' opportunities for the income growth and prosperity needed for self-sufficiency. There is a very high risk of this worsening, rather than improving, as tariffs across the region drop, only to be replaced by nontariff measures (NTMS). There are a variety of reasons for NTMs, and rarely are they deliberately introduced for the sole purpose of obstructing trade. Some may even be well intended, but an alarming statistic is the sheer number of them. This year, the joint survey by the EU-ASEAN Business Council, AsEan Business Advisory Council and Asian Trade Centre published the following findings:

As early as 1987, surveys noted that in spite of progress being made in lifting formal tariffs through initiatives such as 1977 ASEAN PTA Agreement, companies reported having encountered NTMS while trading in ASEAN.

This trend has persisted to this day despite renewed commitment by ASEAN to eliminate NTMS in the signing of the ASEAN Economic Community (AEC) in 2015, which promised the free flow of goods. In fact, according to the Global Database on Non-Tariff Measures (TRAINS), from 2000 to 2015, NTMS in ASEAN rose significantly. Figure 3 shows that the number of sanitary and phytosanitary measures (SPS), technical barriers to trade (TBT) and other types of NTMs increased between 2000 and 2016 by 305,218 and $266 \%$ respectively. This trend is corroborated by other literature. For instance, in a study of nine priority sectors, de Dios found evidence that NTMS remained prevalent despite attempts by ASEAN at NTM-reduction. ${ }^{45}$

This article is in no way critical of NTMs in themselves. It is critical of unnecessary NTMs that, if left unchecked, would simply fester into red tape and present

44 Siow Yue Chia \& Michael G. Plummer, asean Economic Cooperation and Integration: Progress, Challenges and Future Directions 167 (2015).

45 Asian Trade Ctr., Non-Tariff Barriers (NTBs) in ASEAN and Their Elimination from a Business Perspective, European Ass'n for Bus. And Commerce (EABC), at 26 (2019), https://www.eabc-thailand.org/wp-content/uploads/2019/06/NTB_Study_Report_ FINAL.pdf. 
opportunity for corrupt practices. This in turn threatens to hinder any prospect of further growth in the region and erase the success ASEAN has achieved, let alone facilitate progress to an advanced level of regionalism. Many businesses have simply lamented that non-tariff barriers still exist, because ASEAN leaders have been slow to address them owing either to a lack of funding or political interest. These are symptoms. The cause lies in the ASEAN way of "soft diplomacy" coupled with a deep-rooted fear of interfering and being interfered with. Undoubtedly, these inhibit effective checks and balances.

In a system that prizes consensus, consultation, diplomacy and noninterference over "Western" styled concepts of law, order, transparency and the rule of law, any method introduced to monitor compliance must be, and must be seen to be, non-threatening. There are many ways of styling this without saying the "rule of law", but I will conclude this article in the way I started it. Standards and integrity. It is simple and easy to understand. It is a universal concept which can be easily identified with. Every culture and religion either prescribes a form of it, or alludes to it. It does not sound as foreign, abstract and threatening a concept as the "rule of law". Civil servants and the private sector alike, with sufficient motivation, can be taught to adhere to a set of standards and a code of conduct. With practice, it becomes habit, and with habit it becomes culture. This in turn should inspire a fresh environment conducive to overcoming the biggest obstruction to wealth creation and prosperity - the deep-rooted inefficiency caused by years of bureaucracy and red tape regionwide. The scale and context of the challenge ASEAN needs to address is addressed in the next section.

\section{Setbacks: Petty Officialdom, Bureaucracy and Red Tape}

The descriptions in the far-right column are perhaps not very helpful in highlighting what the real issues are, but the rankings are alarming - a tell tale sign that red tape is not being managed. There are some issues that are common across the region, like over-reliance on customs collections for revenue, low civil service salaries and poor training of border officials. But some examples are more country specific than others.

Vietnam has taken strides to simplify its trading processes. But one issue highlighted by the Vietnam Chamber of Commerce and Industry (VCCI) in 2006, which it calls "petty officialdom", remains an issue today. ${ }^{46}$ In that report,

46 David S. Jones, Regulatory Reform and Bureaucracy in Southeast Asia: Variations and Consequences, 8 International Public Management Review 97, 101 (2007). 


\begin{tabular}{|c|c|c|}
\hline Country & $\begin{array}{l}2016 \\
\text { Ranking/136 }\end{array}$ & Top 2 Most Problematic Factors for Importing \\
\hline Singapore & 1 & $\begin{array}{l}\text { 1. High cost or delays caused by international } \\
\text { transportation } \\
\text { 2. Burdensome import procedures }\end{array}$ \\
\hline Malaysia & 47 & $\begin{array}{l}\text { 1. Tariffs and non-tariff barriers } \\
\text { 2. Burdensome import procedures }\end{array}$ \\
\hline Indonesia & 79 & $\begin{array}{l}\text { 1. Corruption at the border } \\
\text { 2. Tariffs and non-tariff barriers }\end{array}$ \\
\hline Thailand & 44 & $\begin{array}{l}\text { 1. Burdensome import procedures } \\
\text { 2. Tariffs and non-tariff barriers }\end{array}$ \\
\hline Vietnam & 86 & $\begin{array}{l}\text { 1. Burdensome import procedures } \\
\text { 2. Tariffs and non-tariff barriers }\end{array}$ \\
\hline Philippines & 93 & $\begin{array}{l}\text { 1. Burdensome import procedures } \\
\text { 2. High cost of delays caused by domestic } \\
\text { transportation }\end{array}$ \\
\hline Cambodia & 116 & $\begin{array}{l}\text { 1. Burdensome import procedures } \\
\text { 2. High cost or delays caused by domestic } \\
\text { transportation }\end{array}$ \\
\hline Lao PDR & 114 & $\begin{array}{l}\text { 1. Tariff and non-tariff barriers } \\
\text { 2. Burdensome import procedures }\end{array}$ \\
\hline
\end{tabular}

SOURCE: WORLD ECONOMIC FORUM GLOBAL ENABLING TRADE REPORT 2016. (AVAILABLE AT: HTTP://WWW3.WEFORUM.ORG/DOCS/WEF_GETR_2016_REPORT.PDF).

a consultant by the name of Nguyen Anh Tuan of Bizconsult "referred to the way officials responsible for business registration refuse to accept an application if minor information is missing. In many cases, businesses have to wait seven days to be informed of just one minor mistake". ${ }^{4}$ More recently in 2015, the VCCI in its survey found that, out of 3000, 28 percent of the companies paid bribes to speed up customs procedures. Those who did not report discrimination, including being treated impolitely and being asked for documents that were not required. ${ }^{48}$ The Central Institute for Economic Management, a

$47 \quad I d$.

4828 Percent of Companies in Vietnam Bribed Customs Officers: Survey, Than H Nien News (Nov. 12, 2015, 8:30 PM), http://www.thanhniennews.com/business/28-percent-of -companies-in-vietnam-bribed-customs-officers-survey-53585.html. 
Vietnam-based think tank, estimates the costs of customs red tape alone to be in the region of US $\$ 10$ billion a year. ${ }^{49}$

Thailand has also its fair share of border-related obstruction to business in the form of its incentive scheme for border officials. According to one source, the reward sharing system at the time of interview provided for "a generous $55 \%$ of penalty recovered from an 'offender' to be distributed as a reward. Of this amount, $30 \%$ is provided to third-party whistleblowers, which may even include other government officers. The remaining $25 \%$ is shared between the customs officials who identified and handled the case". 50

Malaysia's border enforcement activity is typically seasonal, characterized by aggressive, sometimes arbitrary, even irrational challenges to commodity classification. Often this occurs where the opportunity presents itself when a product can reasonably be classified under two or more tariff codes. On the receiving end are importers or their agents, who are unfamiliar with customs classification rules and who will often have their imports re-classified to the highest tariff. ${ }^{51}$ Challenges in Indonesia include excessive import controls and discretionary enforcement. To illustrate this point, when the tsunami disaster struck in 2005, the Financial Times reported that "in Indonesia 1,500 containers are stacked at the Sumatran port of Medan, according to customs records, with 599 of those units unclaimed or needing import permits". ${ }^{2}$

That same report also highlighted Indonesian customs officials saying that "dozens of vehicles destined for Aceh province are still awaiting import permits. Fourteen ambulances recently sent to Indonesia by UNICEF, the United Nations agency for children, took two months to clear customs". ${ }^{3}$ In the case of the Philippines, there is little integration between agencies, as a result of which one agency disrupts another by inadvertently regulating things the regulator did not intend to regulate. In an interview with the CNN, Senator Bam Aquino pointed out "for example, the Philippine National Police tightened rules on importing chemicals to ensure their safety. But in the end, it just made

49 Customs Red Tape Costs Vietnamese Traders \$o Billion a Year: Expert, Thanh Nien News (Aug. 13, 2015, 9:13 PM), http://www.thanhniennews.com/business/customs-red-tape -costs-vietnamese-traders-10-billion-a-year-expert-50046.html.

50 Michael Ramirez\&Anand Udayakumar,Thailand'sCustomsRewardSystem:The SlowMarch Towards Reform, BANG Kок Post (May 16, 2014, 6:04 AM), https://www.bangkokpost.com/ business/409975/thailand-s-customs-reward-system-the-slow-march-towards-reform. Deloitte Touche Tohmatsu, Expect Increased Customs Audits in Years to Come, The NATION ThaILAND (Mar. 11, 2013), https://www.nationthailand.com/Economy/30201693.

$5^{2}$ Red Tape Leaves Tsunami Aid Stranded At Docks, Financial Times (May 12, 2005). Id. 
it harder for chemical industries, like those in the paint business, to bring in their materials". 54

Of course, not every attempt to regulate is necessarily red tape, nor is every obstruction a nefarious gesture. The statistics and interviews in these examples miss one important element - the human element behind the actions, and I hope some personal experience can convey some perspective. In my previous role in 2016, I was part of a lobby group hoping to convince the Ministry of Information and Communication (MIC) in Vietnam to reconsider the regulator's insistence that a tablet (already at that time decided by the World Customs Organization (wCO) Harmonized System Committee (HSC) to be classified as a computing device) be treated for import compliance purposes as a mobile communications device. A computing device did not require an import license, while a mobile communications device did. Then in a regional trade compliance role, my government affairs counterpart and I were tasked with convincing the authorities that a tablet did not connect to mobile networks in the same way a mobile phone did. The head of the MIC department we spoke with empathized but responded saying that they understood the principle, but because the regulation did not clearly distinguish them, "it is better for you to just apply for the license". Put in this way, it is almost innocently human in nature, yet we know that with the right tools, infrastructure, training and resources, this concern could be managed without an obstructive measure. Without this obstruction, businesses could legitimately import tablets that meet safety standards into Vietnam without the need for an additional license - a cost ultimately passed on to consumers. Businesses benefit from this reduced operational cost as much as consumers in turn benefit from lower device costs. The net result is wealth creation from efficiency without compromising consumer protection.

A Means to an End: Forging Rules-Based Solidarity with Standards and Integrity

Not for the lack of desire or political will, ASEAN has in fact committed itself both to a rules-based regional system ${ }^{55}$ and to eliminating NTMS in the signing

54 Claire Jiao, Gov't Eliminates Red Tape in Business Processes, CnN Philippines (June 14, 2016, 1:41 PM), https://cnnphilippines.com/business/2016/06/14/eliminating-red-tape -business.html.

55 ASEAN Economic Community Blueprint, asean Secretariat 5 (2008), https://asean .org/wp-content/uploads/archive/5187-10.pdf. 
of the ASEAN Economic Community (AEC) in 2015 which promised the free flow of goods. ${ }^{56}$ But if we know the consensus model is a perpetual deadlock at the inter-state level, there is very little point in continuing to bang on that door. The rule of law and elimination of NTMs is the end; it is perhaps time to turn our attention to the means. The people actually doing the work can be a powerful place to start - meaning, alleviate the state's inhibitions by appealing to what would actually make people's jobs easier (without compromising national security of course). At the national, district and provincial levels, human beings are tasked with executing tasks. And most do exactly that: Execute tasks.

This is precisely the reason why standards and integrity, instead of the "rule of law", are more relatable, and far more effective in driving compliance at the execution level in a non-threatening way. A universally acceptable ASEAN "code of conduct" leaning in the general direction of a regional set of norms can be inserted into regular operational manuals and training materials for staff and be used to drive cross border collaboration - both for civil service and private sector employees. Private sector employees of multinationals do this very well, given the way corporations operate across borders. To use the tablets import case in Vietnam as an example, supposing Vietnam was truly unsure and hesitant, a governing, or "grandfather" set of standards in place would have allowed them to consult best practices regionally. This code of conduct will need to be localized by each country of course, but because it is not law, it probably does not need to be legislated in order to be implemented. Individual civil servants would likewise be disincentivised from insisting that local standards should prevail. They may very well still do, but probably out of pride or face-saving rather than out of a duty owed to the law. There may very well be instances where local standards must prevail without question. The idea here is to weed out petty officialdom that fuels red tape, like saving precious resources for where they are well and truly needed. This is not interference. It is cooperation at an advanced level.

Integrity can be written into a theme song or code of conduct that is then disseminated through the media, state run channels of communication, industry focus groups, and most importantly, the education system. But as is the case, government officials answer to their respective governments, not to ASEAN. But suppose a standards and ethics monitoring board under the auspices of one of ASEAN's organs was established. How such a body will be staffed and funded is complex and beyond the scope of this article, but it would be extremely effective under the right conditions. Conceptually, the idea must 
first receive support and funding from member states, in particular from those with a chronic fear of interference. In response to such a fear, a reasonable amount of questioning and peer review is not interference. It is checks and balances, albeit one that member states must voluntarily subject themselves to. Interestingly, ASEAN's greatest challenge aside from the ASEAN way is perhaps resources and funding. Even then, when broken into practical bite size initiatives or "projects" with a common goal and interest, the private sector can be mobilized to "adopt" various phases of the projects and implement them.

The skepticism of ASEAN leaders only shows how far we need to think regionalism and progressiveness more generally. It will take some convincing of their merits, but it is a necessary part of progress. 